\title{
Program Keluarga Harapan dan Pemanfaatan Pelayanan Kesehatan Preventif
}

\section{Family Hope Program and Utilization of Preventive Health Care Service}

\author{
Budi Hidayat* Hendratno Tuhiman** Rudy Prawiradinata*** Pungky Sumadi***
}

*Departemen Administrasi dan Kebijakan Kesehatan FKM Universitas Indonesia, **Poverty Reduction and Economic Management The World Bank, ***Direktorat Perlindungan dan Kesejahteraan Masyarakat Badan Perencanaan Pembangunan Nasional

\begin{abstract}
Abstrak
Program keluarga harapan (PKH) yang berbasis bantuan tunai bersyarat (conditional cash transfers, CCT) di bidang pendidikan dan kesehatan telah diluncurkan Pemerintah Indonesia sejak Juli 2007 di 348 kecamatan dari 48 kabupaten/kota di 7 provinsi, namun dampaknya dalam mengurangi angka kemiskinan dan meningkatkan kualitas sumber daya manusia warga miskin belum pernah dievaluasi. Studi ini mengevaluasi dampak awal PKH terhadap penggunaan layanan kesehatan preventif. Evaluasi ini menggunakan rancangan eksperimen, intervensi program PKH berbasis rumah tangga dengan pengukuran sebelum dan sesudah intervensi pada kelompok perlakuan dan kontrol yang sebelumnya dipilih acak pada tingkat kecamatan. Data diperoleh dari survei dasar CCT tahun 2007 dan survei lanjutan PKH tahun 2008 yang dikumpulkan di 6 provinsi. Hasil estimasi metode double-difference menunjukkan dampak program intervensi $\mathrm{PKH}$ pada kenaikan sejumlah indikator pelayanan kesehatan preventif seperti kunjungan posyandu, pemantauan tumbuh kembang anak, dan imunisasi. Temuan ini penting sebagai dasar pengambilan keputusan untuk melanjutkan program. Namun karena evaluasi awal ini memiliki sejumlah keterbatasan, hasil studi ini harus ditafsirkan hati-hati dan divalidasi lebih lanjut dengan data survei PKH tahun 2009 menggunakan berbagai metode analisis

Kata kunci: Evaluasi dampak, bantuan tunai bersyarat, program keluarga harapan, pelayanan kesehatan preventif
\end{abstract}

\section{Abstract}

Family hope program (PKH), a conditional cash transfers (CCT)-based program in education and health, has been launched by the Government of Indonesia since 2007 in 348 sub-districts of 48 regencies/cities in 7 provinces, but its impact on the reduction of poverty and improvement of poor human resources has not been evaluated. This study evaluates initial impact of the PKH on the utilization of preventive healthcare services. This evaluation applies experimental design, a household-based intervention program with measurements prior to and after-intervention in both treatment and control groups that previously were chosen randomly at the sub-district level. The data were obtained from CCT baseline surveys 2007 and PKH follow-up survey 2008 in 6 provinces. Double-difference estimates show the impact of $\mathrm{PKH}$ on the increase of preventive health care services indicators such as visit to posyandu, child growth monitoring, and immunization. These findings are important for decision making to continue the program. However, as this initial evaluation has a number of limitations, this study should be interpreted with caution and be validated further by PKH survey 2009 data using different methods of analysis.

Key words: Impact evaluation, conditional cash transfers, family hope program, preventive health services

\section{Pendahuluan}

Bantuan tunai bersyarat atau conditional cash transfers (CCT) adalah program bantuan tunai yang ditujukan bagi rumah tangga, umumnya kelompok miskin, dengan mensyaratkan mereka melakukan investasi jangka panjang sumber daya manusia (SDM) bagi anak-anaknya. Program ini tercatat sebagai komponen penting sistem perlindungan sosial di banyak negara. Karakteristik utama CCT adalah pemberian bantuan dan mewajibkan perilaku yang terkait dengan investasi SDM seperti pendidikan, kesehatan, dan perbaikan gizi. ${ }^{1}$

Program CCT yang bermula di Meksiko kini banyak diadopsi di berbagai negara. Tidak kurang dari 20 negara Amerika Latin, Karibia, Asia, dan Afrika sudah mengadopsi program CCT dan sekitar 20 negara lainnya

Alamat Korespondensi: Budi Hidayat, Departemen Administrasi dan Kebiijakan Kesehatan FKM Universitas Indonesia Gd. F Lt. 1 Kampus Baru UI Depok 16424, Hp.081519942701,e-mail:b_hidayat@hotmail.com 
sedang memulai. Menyebarnya program CCT ke berbagai dunia tidak terlepas dari fakta empiris akan keberhasilan program. CCT terbukti berhasil mengurangi angka kemiskinan dan mendorong orangtua melakukan investasi kesehatan dan pendidikan bagi anak-anak. Progam ini juga menyokong pemenuhan target-target indikator tujuan pembangunan milenium (Millenium Development Goals, MDGs) seperti pengurangan penduduk miskin dan kelaparan, pencapaian pendidikan dasar, kesetaraan gender, pengurangan angka kematian bayi dan balita serta pengurangan kematian ibu karena melahirkan. ${ }^{1}$

Pemerintah Indonesia turut menaruh perhatian pada keberadaan program CCT. Pada bulan Juli 2007, pemerintah meluncurkan sebuah uji coba program CCT yang diberi nama Program Keluarga Harapan (PKH). PKH terdiri atas dua komponen, yaitu pendidikan dan kesehatan. ${ }^{2}$ Komponen kesehatan mensyaratkan pesertanya menggunakan layanan prenatal, proses kelahiran harus ditolong oleh tenaga kesehatan terlatih, layanan postnatal serta mengimunisasikan anak dan memantau tumbuh kembang anak secara rutin. Sedangkan, komponen pendidikan mensyaratkan anak-anak peserta $\mathrm{PKH}$ wajib terdaftar dan hadir di sekolah minimal $85 \%$ dari jumlah hari sekolah yang berlaku. Penetapan persyaratan ini diharapkan akan membawa perubahan perilaku peserta PKH terhadap pentingnya kesehatan dan pendidikan bagi anak-anaknya.

Uji coba PKH 2007 dilakukan di 7 provinsi (DKI Jakarta, Jawa Barat, Jawa Timur, Sulawesi Utara, Gorontalo, dan Nusa Tenggara Timur) dengan target peserta 500.000 rumah tangga. Ketujuh provinsi tersebut dipilih atas dasar kesediaan pemerintah provinsi yang disampaikan ketika Musyawarah Perencanaan Pembangunan Nasional (Musrenbangnas) pada tahun 2006 yang dilaksanakan oleh Badan Perencanaan Pembangunan Nasional (Bappenas) setiap tahun untuk menyelaraskan rencana pembangunan sektoral dan pembangunan daerah dan keberagaman karakteristik seperti tingkat kemiskinan (tinggi, sedang atau rendah), daerah (desa/kota, kepulauan/pesisir), dan aksesibilitas (mudah/sulit). Berdasarkan 7 provinsi uji coba terpilih selanjutnya dipilih sejumlah kabupaten/kota dan kecamatan dengan menggunakan kriteria tingginya angka kemiskinan, angka gizi buruk, dan angka transisi dari SD/MI ke SMP/MTS, ketersediaan sarana dan prasarana baik pendidikan maupun kesehatan serta adanya kesediaan dan komitmen daerah untuk menjamin ketersediaan pelayanan kesehatan dan pendidikan. Berdasarkan kriteria ini, telah dipilih 48 kabupaten/kota dan 348 kecamatan sebagai daerah uji coba PKH 2007. Sedangkan, target peserta PKH 2007 adalah rumah tangga dengan kategori sangat miskin (RTSM) yang memiliki anggota keluarga terdiri dari ibu hamil dan/atau anak-anak berusia dibawah 15 tahun atau lebih dari 15 tahun, namun belum menyelesaikan pendidikan dasar. ${ }^{2}$

Ide dasar uji coba PKH adalah untuk menguji berbagai instrumen $\mathrm{PKH}$, termasuk targeting, verifikasi komitmen, mekanisme pembayaran, sistem pemutakhiran data serta pengaduan. Uji coba tidak dimaksudkan untuk menguji keberadaan program. Pemerintah sudah menempatkan PKH sebagai embrio dan komponen penting pada pengembangan sistem perlindungan sosial. ${ }^{2}$

Namun demikian, pengembangan PKH perlu dilakukan atas dasar keberhasilan program dalam memenuhi tujuannya yakni mengurangi angka kemiskinan dan meningkatkan kualitas SDM warga miskin. ${ }^{3}$ Keberhasilan tersebut harus dibuktikan secara empiris sehingga memiliki dasar yang dapat dipertanggungjawabkan. Untuk maksud ini, Bappenas membuat rencana evaluasi ketika merancang PKH pada pertengahan tahun 2006. Penelitian ini merupakan implementasi dari rencana program evaluasi PKH tersebut. Dengan mengoptimalkan ketersediaan data survei dasar CCT 2007 dan survei lanjutan PKH 2008, penelitian ini bertujuan untuk memotret dampak PKH. Tujuan khususnya adalah untuk mendeteksi dampak awal PKH terhadap penggunaan layanan kesehatan preventif yaitu kunjungan posyandu, pemantauan tumbuh kembang anak, dan imunisasi.

\section{Metode}

Studi ini menggunakan rancangan eksperimen. Desain ini mensyaratkan keberadaan kelompok intervensi dan kontrol yang memiliki karakteristik homogen sebelum program dilaksanakan. ${ }^{4}$ Rancangan eksperimen dipilih mengingat pengukuran dampak membutuhkan pemahaman tentang fenomena apa yang terjadi jika sebuah intervensi tidak dilakukan. Pada konteks ini dibutuhkan ukuran counterfactual mengenai fenomena yang terjadi jika tidak ada intervensi. Cara efektif mendesain counterfactual adalah memilih kelompok, intervensi, kontrol, dan acak. Strategi randomisasi ini telah digunakan pada pemilihan lokasi (kecamatan) PKH dan non PKH. ${ }^{5}$

Data yang digunakan dalam studi ini diperoleh dari hasil survei dasar CCT 2007 dan survei lanjutan PKH 2008. Survei dasar CCT dikumpulkan bulan Oktober 2007 di 6 provinsi dari 7 provinsi uji coba. Sampel survei kabupaten terdiri atas 44 dari 48 kabupaten lokasi uji coba. Sebanyak 44 kabupaten selanjutnya dipilih 360 sampel kecamatan kontrol (180) dan intervensi (180) secara acak dengan stratifikasi pada tingkat desa/kota. Sedangkan, pemilihan sampel rumah tangga dilakukan secara purposive dari daftar rumah tangga penerima bantuan langsung tunai (BLT) tahun 2005 (kerangka sampel). Pemilihan sampel rumah tangga secara acak diduga menghasilkan sampel intervensi cukup kecil jika cakupan PKH relatif kecil terhadap populasi. ${ }^{5}$ Survei lan- 
jutan PKH dikumpulkan setahun setelah uji coba PKH di lokasi yang sama dengan lokasi survei dasar. Mengingat pelaksanaan uji coba PKH belum optimal, tidak semua sampel survei dasar dijadikan sebagai sampel dalam survei lanjutan. ${ }^{6}$ Sebanyak 360 kecamatan dengan 2.723 desa sampel pada survei dasar hanya 196 kecamatan dan 343 desa (2 desa per kecamatan) yang dijadikan sampel pada survei lanjutan. ${ }^{7}$

Untuk menghitung rata-rata dampak, studi ini menggunakan difference-in-difference atau double-difference (DD). ${ }^{8}$ Metode ini digunakan karena data rumah tangga, baik kontrol maupun intervensi, dikumpulkan sebelum dan sesudah uji coba. Tabel 1 menyajikan skenario perhitungan metode DD. Pada bagian kolom membedakan 2 kelompok, intervensi (I) dan kontrol (C), sedangkan baris membedakan tahapan survei, sebelum (indeks 0) dan sesudah intervensi (indeks 1). Sebagai contoh ilustrasi, akan diukur dampak PKH terhadap imunisasi. Sebelum intervensi, cakupan imunisasi akan sama diantara kedua kelompok (karena randomisasi), sedangkan setelah intervensi diharapkan ada perbedaan cakupan imunisasi. Perbedaan cakupan imunisasi setelah intervensi, $\left(\mathrm{I}_{1}-\mathrm{C}_{1}\right)$, merupakan ukuran rata-rata dampak dan ini disebut sebagai perbedaan awal (firstdifference). Pengukuran dampak yang valid harus mempertimbangkan perbedaan kondisi awal, baik terukur (observed) maupun tidak terukur (unobserved) pada kelompok intervensi dan kontrol. Estimasi DD dilakukan dengan mengurangkan perbedaan kondisi sebelum intervensi diantara kedua kelompok, $\left(\mathrm{I}_{0}-\mathrm{C}_{0}\right)$, dengan perbedaan setelah intervensi, $\left(\mathrm{I}_{1}-\mathrm{C}_{1}\right)$ (Lihat Tabel 1).

Gambar 1 menyajikan interpretasi estimasi DD. ${ }^{4}$ Oleh karena proses randomisasi, indikator evaluasi pada awal program (sebelum intervensi) memiliki nilai hampir sama diantara kelompok intervensi dan kontrol, ini digambarkan oleh titik K. Pengukuran dampak yang hanya memperhatikan indikator evaluasi pada kelompok intervensi akan menghasilkan efek program berlebihan yakni M-K. Perhitungan efek murni harus memperhatikan kondisi indikator evaluasi kelompok kontrol yang memiliki kecenderungan perbaikan dari waktu ke waktu (L-K).

\section{Hasil}

Tabel 2 kolom pertama menyajikan kondisi awal indikator-indikator penggunaan layanan kesehatan preventif. Indikator tersebut diperoleh dari analisis data survei dasar untuk 2 jenis sampel: (i) semua sampel (sampel-total) dan (ii) sampel survei dasar yang diwawancara kembali pada survei lanjutan (sampel panel). Jumlah totalsampel rumah tangga intervensi dan kontrol masingmasing 3.091 dan 3.077, sedangkan sampel panel hanya 292 dan 364 rumah tangga.

Tabel 2 juga menyajikan uji beda rata-rata untuk mendeteksi hipotesis nol homogenitas indikator evaluasi kondisi awal. Pada sampel total, meskipun ada perbedaan proporsi diantara kedua kelompok, tidak satu pun hasil uji menunjukan perbedaan bermakna. Seluruh hasil uji menerima hipotesis kesamaan proporsi diantara kedua kelompok intervensi dan kontrol. Namun, hasil uji pada sampel panel untuk imunisasi BCG menunjukan perbedaan bermakna $(\mathrm{p}<5 \%)$. Cakupan imunisasi BCG kelompok intervensi $(86 \%)$ secara statistik proporsinya lebih tinggi daripada cakupan serupa kelompok kontrol $(78 \%)$. Artinya, cakupan imunisasi BCG diantara kedua kelompok pada awal intervensi tidak homogen. Ini me-

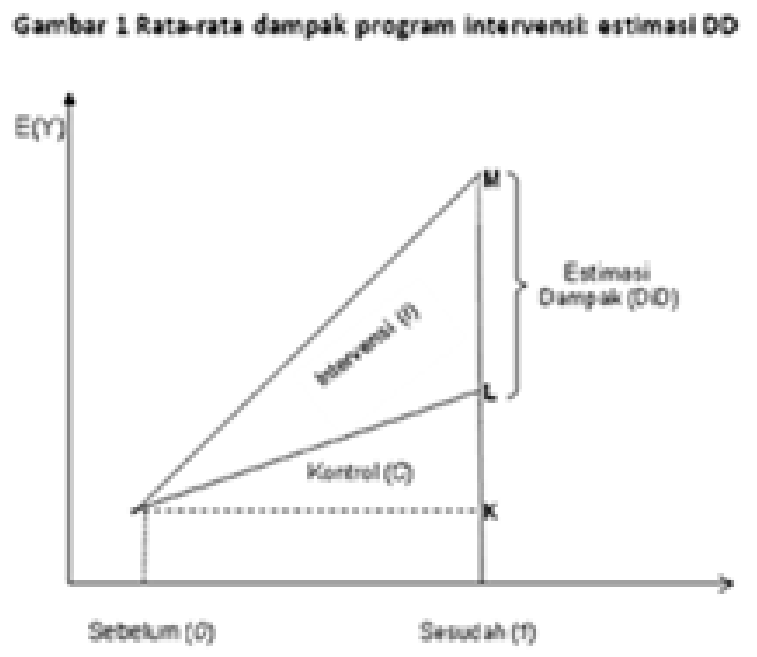

Gambar 1. Rata-rata Dampak Program Intervensi: Estimasi DD

Tabel 1. Metode Double-Difference untuk Menghitung Rata-rata Dampak PKH

\begin{tabular}{lccc}
\hline Tahapan Survei & $\begin{array}{c}\text { Kelompok Intervensi } \\
\text { (dengan PKH) }\end{array}$ & $\begin{array}{c}\text { Kelompok Kontrol } \\
\text { (tanpa PKH) }\end{array}$ & Perbedaan Antarkelompok \\
\hline $\begin{array}{l}\text { Lanjutan (follow-up) } \\
\text { Dasar (baseline) }\end{array}$ & $\mathrm{I}_{1}$ & $\mathrm{C}_{1}$ & $\left(\mathrm{I}_{1}-\mathrm{C}_{1}\right)$ \\
Perbedaan antar waktu & $\mathrm{I}_{0}$ & $\mathrm{C}_{0}$ & $\left(\mathrm{C}_{0}-\mathrm{C}_{0}\right)$ \\
& $\left(\mathrm{I}_{1}-\mathrm{I}_{0}\right)$ & $\left(\mathrm{C}_{1}-\mathrm{C}_{0}\right)$ & $\begin{array}{c}\text { Double-Difference } \\
\left(\mathrm{I}_{1}-\mathrm{C}_{1}\right)-\left(\mathrm{I}_{0}-\mathrm{C}_{0}\right)\end{array}$ \\
\hline
\end{tabular}


Tabel 2. Statistik Deskriptif Survei Dasar (Baseline Survey)

\begin{tabular}{|c|c|c|c|c|c|c|c|c|}
\hline \multirow[t]{2}{*}{ Indikator Kesehatan } & \multicolumn{3}{|c|}{ Sampel Total } & \multicolumn{4}{|c|}{ Sampel Panel } & \multirow[b]{2}{*}{ Nilai $p$} \\
\hline & $\begin{array}{l}\text { Intervensi } \\
\text { (I) }\end{array}$ & $\begin{array}{l}\text { Kontrol } \\
\text { (C) }\end{array}$ & $\begin{array}{l}\text { Beda } \\
(\text { I-C) }\end{array}$ & Nilai p & $\begin{array}{l}\text { Intervensi } \\
\text { (I) }\end{array}$ & $\begin{array}{l}\text { Kontrol } \\
\text { (C) }\end{array}$ & $\begin{array}{l}\text { Beda } \\
(I-C)\end{array}$ & \\
\hline Kunjungan posyandu & 77,58 & 78,00 & $-0,42$ & 0,98 & 70,89 & 73,63 & $-2,74$ & 0,54 \\
\hline Timbang berat badan & 76,51 & 76,47 & 0,04 & 0,48 & 67,47 & 72,80 & $-5,34$ & 0,23 \\
\hline Memiliki KMS & 44,68 & 45,56 & $-0,89$ & 0,69 & 45,55 & 40,66 & 4,89 & 0,69 \\
\hline Memiliki buku KIA & 33,74 & 33,08 & 0,66 & 0,83 & 39,04 & 33,79 & 5,25 & 0,33 \\
\hline Melakukan imunisasi & 30,73 & 29,57 & 1,6 & 0,89 & 27,05 & 28,57 & $-1,52$ & 0,35 \\
\hline Imunisasi BCG & 78,00 & 77,77 & 0,23 & 0,89 & 86,30 & 78,30 & 8,00 & $0,02 * *$ \\
\hline Imunisasi polio 1 & 77,03 & 75,95 & 1,08 & 0,51 & 80,14 & 78,85 & 1,29 & 0,70 \\
\hline Imunisasi polio 2 & 65,09 & 64,61 & 0,48 & 0,81 & 71,23 & 68,68 & 2,55 & 0,52 \\
\hline Imunisasi polio 3 & 55,58 & 54,44 & 1,14 & 0,60 & 58,90 & 58,52 & 0,39 & 0,93 \\
\hline Imunisasi polio 4 & 42,80 & 43,29 & $-0,49$ & 0,82 & 43,49 & 43,41 & 0,09 & 0,98 \\
\hline Imunisasi DPT 1 & 66,71 & 66,53 & 0,18 & 0,93 & 74,32 & 69,23 & 5,08 & 0,22 \\
\hline Imunisasi DPT 2 & 56,81 & 56,74 & 0,07 & 0,98 & 65,75 & 58,52 & 7,24 & 0,11 \\
\hline Imunisasi DPT 3 & 48,59 & 48,75 & $-0,16$ & 0,95 & 53,77 & 49,45 & 4,32 & 0,36 \\
\hline Imunisasi campak & 50,92 & 49,82 & 1,10 & 0,98 & 50,68 & 49,73 & 0,96 & 0,83 \\
\hline Imunisasi hepatitis B 1 & 64,22 & 64,35 & $-0,13$ & 0,48 & 69,52 & 64,84 & 4,69 & 0,25 \\
\hline Imunisasi hepatitis B 2 & 51,02 & 51,61 & $-0,59$ & 0,69 & 58,90 & 54,12 & 4,78 & 0,29 \\
\hline Imunisasi hepatitis B 3 & 43,25 & 44,62 & $-1,37$ & 0,83 & 48,63 & 46,70 & 1,93 & 0,68 \\
\hline No. Observasi & 3,091 & 3,077 & & & 292 & 364 & & \\
\hline
\end{tabular}

Catatan: Hasil analisis data survei dasar (baseline) CCT 2007. Sampel total adalah semua rumah tangga yang dicacah dalam survei dasar. Sampel panel adalah rumah tangga yang dicacah pada survei dasar 2007 dan survei lanjutan PKH 2008.

rupakan keterbatasan dalam penggunaan DD. Diskusi lanjut terkait isu ini dasajikan dalam pembahasan.

\section{Dampak PKH dan Program Lain}

Tabel 3 menyajikan perbedaan indikator evaluasi hasil analisis data survei dasar dan survei lanjutan untuk kelompok intervensi dan kontrol. Kolom kelompok intervensi dan kelompok kontrol menyajikan nilai proporsi, perbedaan proporsi (angka absolut dan persen) serta $p$-value uji beda rata-rata kedua tahapan survei. Tampak bahwa proporsi indikator yang dihasilkan dari analisis data survei lanjutan nilainya lebih tinggi daripada proporsi indikator hasil analisis data survei dasar. Temuan ini semuanya signifikan ( $p$-value $<5 \%$ ), baik untuk rumah tangga intervensi maupun rumah tangga kontrol.

Sebanyak 71 dari 100 bayi dari kelompok rumah tangga intervensi berkunjung ke posyandu pada awal program (survei dasar). Angka kunjungan ini naik menjadi 96 per 100 bayi setelah intervensi PKH (survei lanjutan). Kondisi serupa ditemukan pada rumah tangga kontrol, namun kenaikannya lebih kecil $(30,3 \%)$ dibandingkan kenaikan pada rumah tangga intervensi yang hanya naik $35,7 \%$. Indikator penimbangan berat badan bayi, proporsinya naik dari $67 \%$ pada awal program menjadi 93\% (naik 38,6\%). Proporsi kenaikan indikator penimbangan berat badan bayi rumah tangga intervensi (38\%) juga lebih tinggi dibandingkan dengan rumah tangga kontrol (29\%). Demikian halnya untuk indikator imunisasi, rumah tangga intervensi mengalami kenaikan $237 \%$, sedangkan pada rumah tangga kontrol hanya $222 \%$. Pola yang sama ditemukan untuk indikator imunisasi campak, polio 3, dan polio 4 .

Kondisi dimana kenaikan didominasi oleh rumah tangga kontrol ditemukan juga pada sejumlah indikator. Misalnya, kenaikan proporsi rumah tangga intervensi yang memiliki kartu menuju sehat (KMS) dan buku kesehatan ibu dan anak (KIA) masing-masing 89\% dan $50 \%$. Sementara itu, kenaikan pada rumah tangga kontrol mencapai $110 \%$ dan 56\%. Kenaikan indikator imunisasi BCG, polio 2, DPT, dan hepatitis juga didominasi oleh rumah tangga kontrol. Gambar 2 menyajikan perbedaan proporsi indikator survei dasar dan survei lanjutan, baik untuk kelompok intervensi maupun kontrol.

\section{Dampak Murni PKH}

Mengingat kelompok intervensi dan kontrol dipilih acak maka perbedaan hasil antara survei dasar dengan survei lanjutan menunjukkan dampak perbedaan tersebut akibat intervensi PKH. Proporsi kunjungan posyandu kelompok PKH pada awal intervensi $(71 \%)$ dan naik menjadi $96 \%$ setahun setelah intervensi atau terjadi perbedaan proporsi $25 \%$. Ini menunjukkan bahwa intervensi PKH setahun meningkatkan kunjungan 36\%. Sementara itu, kenaikan kunjungan posyandu 30\% (naik 
Tabel 3. Perbedaan Indikator Evaluasi Survei Dasar 2007 dan Survei Lanjutan 2008

\begin{tabular}{|c|c|c|c|c|c|c|c|c|c|c|}
\hline \multirow[t]{2}{*}{ Indikator Tujuan } & \multicolumn{5}{|c|}{ Kelompok Intervensi } & \multicolumn{4}{|c|}{ Kelompok Kontrol } & \multirow[b]{2}{*}{ Nilai $\mathrm{p}$} \\
\hline & $\begin{array}{c}\text { Survei } \\
\text { Dasar }\end{array}$ & $\begin{array}{l}\text { Survei } \\
\text { Lanjut }\end{array}$ & Beda & $\%$ beda & Nilai $\mathbf{p}$ & $\begin{array}{l}\text { Survei } \\
\text { Dasar }\end{array}$ & $\begin{array}{l}\text { Survei } \\
\text { Lanjut }\end{array}$ & Beda & $\%$ beda & \\
\hline Kunjungan posyandu & 70,89 & 96,23 & 25,34 & 35,7 & $0,00^{* * *}$ & 73,55 & 95,87 & 22,31 & 30,3 & $0,00^{* * *}$ \\
\hline Timbang berat badan & 67,47 & 93,49 & 26,03 & 38,6 & $0,00^{* *}$ & 72,73 & 93,94 & 21,21 & 29,2 & $0,00^{* * *}$ \\
\hline Memiliki KMS & 45,55 & 85,96 & 40,41 & 88,7 & $0,00^{* * *}$ & 40,77 & 85,67 & 44,90 & 110,1 & $0,00^{* * *}$ \\
\hline Memiliki buku KIA & 39,04 & 58,56 & 19,52 & 50,0 & $0,00^{* * *}$ & 33,61 & 52,62 & 19,01 & 56,6 & $0,00^{* * *}$ \\
\hline Melakukan imunisasi & 27,05 & 91,10 & 64,04 & 236,7 & $0,00^{* *}$ & 28,65 & 92,29 & 63,64 & 222,1 & $0,00^{* * *}$ \\
\hline Imunisasi BCG & 86,30 & 97,60 & 11,30 & 13,1 & $0,00^{* * *}$ & 78,24 & 94,49 & 16,25 & 20,8 & $0,00^{* * *}$ \\
\hline Imunisasi polio 1 & 80,14 & 98,63 & 18,49 & 23,1 & $0,00^{* * *}$ & 78,79 & 96,42 & 17,63 & 22,4 & $0,00^{* * *}$ \\
\hline Imunisasi polio 2 & 71,23 & 96,58 & 25,34 & 35,6 & $0,00^{* * *}$ & 68,87 & 94,21 & 25,34 & 36,8 & $0,00^{* * *}$ \\
\hline Imunisasi polio 3 & 58,90 & 95,55 & 36,64 & 62,2 & $0,00^{* * *}$ & 58,68 & 92,84 & 34,16 & 58,2 & $0,00^{* * *}$ \\
\hline Imunisasi polio 4 & 43,49 & 95,21 & 51,71 & 118,9 & $0,00^{* *}$ & 43,53 & 90,91 & 47,38 & 108,9 & $0,00^{* * *}$ \\
\hline Imunisasi DPT 1 & 74,32 & 98,63 & 24,32 & 32,7 & $0,00^{* * *}$ & 69,15 & 94,49 & 25,34 & 36,7 & $0,00^{* * *}$ \\
\hline Imunisasi DPT 2 & 65,75 & 96,92 & 31,16 & 47,4 & $0,00^{* * *}$ & 58,68 & 92,56 & 33,88 & 57,7 & $0,00^{* * *}$ \\
\hline Imunisasi DPT 3 & 53,77 & 95,55 & 41,78 & 77,7 & $0,00^{* * *}$ & 49,59 & 90,36 & 40,77 & 82,2 & $0,00^{* * *}$ \\
\hline Imunisasi campak & 50,68 & 97,26 & 46,58 & 91,9 & $0,00^{* * *}$ & 49,86 & 94,77 & 44,90 & 90,1 & $0,00^{* * *}$ \\
\hline Imunisasi hepatitis 1 & 69,52 & 94,52 & 25,00 & 36,0 & $0,00^{* *}$ & 64,74 & 91,18 & 26,45 & 40,9 & $0,00^{* * *}$ \\
\hline Imunisasi hepatitis 2 & 58,90 & 92,12 & 33,22 & 56,4 & $0,00^{* * *}$ & 54,27 & 91,46 & 37,19 & 68,5 & $0,00^{* * *}$ \\
\hline Imunisasi hepatitis 3 & 48,63 & 92,12 & 43,49 & 89,4 & $0,00^{* * *}$ & 46,83 & 89,81 & 42,98 & 91,8 & $0,00^{* * *}$ \\
\hline No Observasi & 292 & 292 & & & & 364 & 364 & & & \\
\hline
\end{tabular}

dari 74\% menjadi 96\%) juga ditemukan pada kelompok kontrol. Dengan mengurangi perbedaan proporsi kondisi awal diantara kedua kelompok dengan perbedaan diantara keduanya setelah intervensi $(0,4 \%-(-2,7 \%))$ diperoleh perbedaan 3,1\%. Meskipun tidak signifikan, perbedaan proporsi ini menunjukkan rata-rata dampak murni PKH terhadap kunjungan bayi usia 0-36 bulan ke posyandu sebesar 3,1\%.

Hasil penelitian ini memperlihatkan perpedaan proporsi penimbangan bayi usia 0-12 bulan pada rumah tangga intervensi antara survei lanjutan dengan survei dasar mencapai $26 \%$, sementara pada rumah tangga kontrol hanya beda $21 \%$. Berdasarkan tahapan waktu, penimbangan bayi rumah tangga intervensi pada saat survei dasar lebih rendah 5,3\% dibandingkan penimbangan bayi rumah tangga kontrol. Sedangkan, pada saat survei lanjutan penimbangan bayi rumah tangga intervensi hanya lebih rendah $0,5 \%$ dibandingkan dengan rumah tangga kontrol. Uji beda rata-rata antara rumah tangga kontrol dan intervensi tidak menunjukkan perbedaan signifikan. Dengan mengurangi perbedaan proporsi kondisi awal diantara kedua kelompok rumah tangga dengan perbedaan setelah intervensi, diperoleh rata-rata PKH menaikkan kegiatan pemantauan tumbuh kembang anak sebesar $4,9 \%$.

Uji coba PKH juga menunjukkan sinyalemen positif terkait dengan kegiatan imunisasi anak usia kurang dari setahun yang mengalami rata-rata kenaikan 0,3\%.
Perbandingan rata-rata kegiatan imunisasi antara rumah tangga intervensi ketika survei dasar 1,5\% lebih rendah dibandingkan dengan rumah tangga kontrol pada survei yang sama. Sementara itu, rata-rata kegiatan imunisasi antara rumah tangga intervensi dibandingkan rumah tangga kontrol ketika survei lanjutan hanya 1,2\% lebih rendah. Perbedaan antar survei menunjukkan bahwa kegiatan imunisasi rumah tangga intervensi (64\%) lebih tinggi sedikit dibandingkan rumah tangga kontrol $(63,7 \%)$. Namun hasil uji beda 2 rata-rata tidak menunjukkan perbedaan signifikan baik menurut seri waktu maupun kelompok rumah tangga.

\section{Pembahasan}

Studi ini menemukan kenaikan penggunaan layanan kesehatan preventif baik pada kelompok rumah tangga intervensi maupun kontrol. Temuan ini mengindikasikan bahwa kenaikan penggunaan layanan kesehatan tidak hanya dipengaruhi oleh PKH, tetapi juga programprogram lain. Kemungkinan adalah program rutin Kementerian Kesehatan RI yang digulirkan oleh puskesmas dalam bentuk kegiatan/program yang diberikan baik di dalam maupun di luar gedung. Pengukuran dampak yang hanya memperhatikan perbedaan pada kelompok intervensi dapat menghasilkan kesimpulan yang tidak tepat atau dampak berlebihan. Merujuk pada temuan yang disajikan pada Tabel 3 (kolom intervensi), PKH dapat disimpulkan berhasil menaikkan kunjungan posyandu se- 


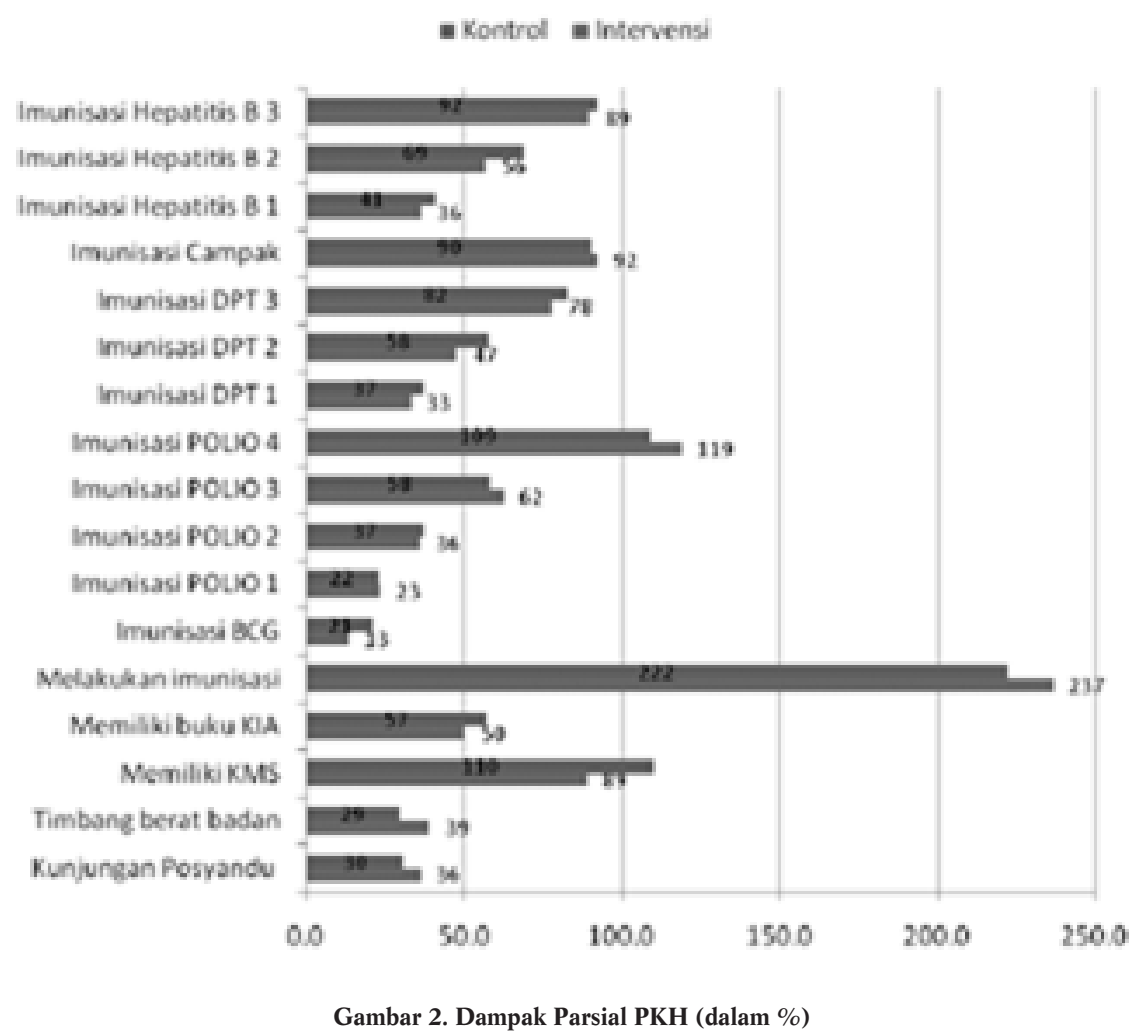

besar 36\%. Padahal, temuan tersebut tidak memperhatikan kondisi yang terjadi pada rumah tangga kontrol yang juga mengalami kenaikan sebesar $30 \%$. Untuk menghitung dampak murni program intervensi PKH, studi ini mengadopsi metode DD yang memperhatikan perbedaan tidak hanya pada rumah tangga intervensi tetapi juga rumah tangga kontrol.

Merujuk pada hasil estimasi DD, studi ini menemukan rata-rata dampak murni PKH terhadap kunjungan posyandu hanya $3 \%$. Tidak signifikansinya uji beda 2 rata-rata hasil estimasi DD, tingkat kepercayaan lebih besar dari 5\% disebabkan oleh sejumlah faktor. Pertama, sedikitnya sampel yang digunakan dalam analisis. Sampel rumah tangga survei dasar mencapai 6.168 rumah tangga dengan komposisi 3.091 (intervensi) dan 3.077 (kontrol). Namun demikian, survei lanjutan PKH 2008 hanya menggali informasi dari sekitar $11 \%$ responden survei dasar. Analisis data dalam studi ini dengan terpaksa hanya dapat menggunakan sampel panel yang berjumlah 656 rumah tangga. Sedikitnya, jumlah sampel mempengaruhi standar eror uji beda 2 rata-rata dan jauh dibawah perhitungan kekuatan sampel (power calculations) untuk mendeteksi dampak program. Kedua, tidak seimbangnya jumlah sampel antara kelompok kontrol dan intervensi. Sebanyak 656 rumah tangga sampel panel yang berhasil dianalisis, jumlah sampel rumah tangga kontrol 1,4 kali lebih besar dibandingkan sampel rumah tangga intervensi yang hanya 292 rumah tangga. Penolakan hipotesis nol pada uji homogenitas antara kelompok kontrol dan intervensi pada awal survei untuk sampel panel turut mempengaruhi penggunaan metode DD.

Kemungkinan ketiga adalah efek kontaminasi program intervensi (spillover effects). Studi ini menemukan 708 rumah tangga dengan status intervensi menurut survei dasar, namun setelah dilacak dengan survei lanjutan sekitar 22\% rumah tangga tersebut teridentifikasi sebagai kelompok kontrol. Sebaliknya juga, ditemukan dimana dari 830 rumah tangga kontrol menurut survei dasar, 152 rumah tangga $(18,3 \%)$ berubah status menjadi rumah tangga intervensi. ${ }^{3}$ Perubahan status rumah tangga kelompok kontrol menjadi intervensi secara logika tidak boleh terjadi karena rumah tangga, misal kelompok kontrol berada di lokasi kecamatan kontrol. Padahal lokasi uji coba (kecamatan intervensi dan kontrol) sebelumnya dipilih secara random. ${ }^{5}$ Temuan ini 
mengindikasikan: (i) pelaksana evaluasi (evaluator) tidak mampu menjamin kelompok kontrol bebas dari kontaminasi program intervensi dan (ii) minimnya koordinasi pelaksana evaluasi dengan pelaksana program untuk menjaga daerah kontrol yang sudah ditetapkan pada awal intervensi. Tidak heran jika studi ini menemukan kenaikan kunjungan sejumlah indikator evaluasi pada rumah tangga kontrol.

Meskipun secara statistik tidak signifikan, temuan studi ini konsisten dengan karakteristik PKH yang mewajibkan peserta untuk secara rutin melakukan kunjungan ke fasilitas kesehatan, termasuk ke posyandu. ${ }^{9}$ Temuan studi juga sejalan dengan hasil evaluasi dampak CCT di sejumlah negara. Gertler, ${ }^{10}$ melaporkan CCT di Meksiko meningkatkan kunjungan di fasilitas kesehatan rata-rata 2,09 kunjungan per hari. Peserta CCT berkunjung ke fasilitas kesehatan 2 kali lebih sering daripada non-penerima. Hasil studi evaluasi CCT di Honduras melaporkan adanya peningkatan kunjungan secara signifikan $23 \%$ bagi bayi usia kurang dari 1 tahun dan $42 \%$ bagi anak usia prasekolah. ${ }^{11}$ Studi di Nikaragua melaporkan rata-rata persentase kenaikan 19\% setelah 1 tahun pelaksanaan dan $11 \%$ setelah 2 tahun pada proporsi bayi (usia 0-3 tahun) yang dibawa ke pusat-pusat kesehatan selama 6 bulan terakhir.

Posyandu yang dikelola oleh para kader dengan bantuan bidan desa dan tenaga paramedis lain dari puskesmas umumnya mampu memberikan layanan antenatal bagi ibu-ibu hamil, penimbangan berat badan bayi, penyuluhan kesehatan, dan imunisasi. ${ }^{12}$ Oleh karenanya, naiknya kunjungan bayi PKH ke posyandu berimplikasi juga pada kenaikan proporsi bayi yang ditimbang berat badannya. Studi ini mendeteksi kenaikan penimbangan bayi secara rata-rata sebesar 5\%. Temuan ini konsisten dengan hasil evaluasi dampak CCT di Honduras yang berhasil menaikkan kegiatan pemantauan tumbuh kembang anak $16 \% .{ }^{13}$

Meskipun PKH menaikkan kegiatan imunisasi, persentase kenaikannya relatif sangat kecil (hanya naik 0,3\%). Bahkan untuk sejumlah indikator imunisasi (seperti BCG, polio 2, DPT1, DPT2, hepatitis 1, dan hepatitis 2) memiliki dampak negatif. Empat studi menganalisis dampak CCT terhadap cakupan imunisasi dengan hasil yang kurang jelas. Misalnya Barham, ${ }^{14}$ menganalisis dampak Oportunidades pada imunisasi tuberkulosis dan campak. Efek program dilaporkan sangat kecil dan tidak signifikan karena cakupan imunisasi pada awal program sangat tinggi (90\%). Berbeda dengan Indonesia, cakupan imunisasi pada awal uji coba dibawah 38\%. Dibandingkan dengan sebelum intervensi, cakupan kegiatan imunisasi mengalami kenaikan yang sangat signifikan yaitu naik dari $27 \%$ menjadi $91 \%$ atau terjadi kenaikan sebesar $237 \%$ setelah setahun intervensi PKH. Namun, kenaikan $222 \%$ juga terjadi pada kelompok ru- mah tangga kontrol sehingga dampak murni PKH dalam mendongkrak cakupan kegiatan imunisasi relatif kecil.

Di Kolombia, Attanasio, 15 menemukan dampak positif program CCT, Familias en Acción, terhadap kegiatan imunisasi, tetapi dampaknya juga tidak signifikan. Programa de Asignacion Familiar (PRAF) di Honduras meningkatkan cakupan imunisasi difteri, pertusis, tetanus, tetapi tidak untuk campak. Barham dkk, ${ }^{16}$ menemukan dampak CCT di Nikaragua Red de Proteccion Social (RPS) terhadap cakupan vaksinasi. Program CCT di Turki berhasil meningkatkan cakupan imunisasi yakni anak-anak dibawah usia 6 tahun yang diimunisasi lengkap 14\% lebih tinggi diantara mereka yang berpartisipasi dalam CCT. Evaluasi CCT di Honduras menunjukkan peningkatan rata-rata $6,9 \%$ dalam jangkauan dosis pertama difteri, tetanus toxoids, pertusis (antigen tidak ditentukan) pentavalent vaksin pada anak-anak muda dari 3 tahun, tetapi tidak berpengaruh pada vaksinasi campak atau pada tetanus imunisasi diantara wanita hamil. Program CCT di Kolombia meningkatkan probabilitas bahwa orangtua telah mematuhi imunisasi difteri, tetanus toxoids, pertusis (antigen tidak ditentukan), jadwal vaksinasi anak-anak mereka pada usia 24 bulan, meskipun tidak terlihat efek jelas pada cakupan. Program CCT di Nikaragua gagal menunjukkan peningkatan cakupan imunisasi, meskipun disinyalir ada efek kontaminasi tidak langsung dari program pemberian vaksin yang memiliki efek positif pada ketersediaan vaksin di daerah kontrol.

\section{Keterbatasan Studi}

Kenaikan penggunaan kesehatan preventif tidak selalu menunjukkan perbaikan kualitas layanan maupun perbaikan status kesehatan peserta PKH. Namun demikian, studi ini hanya melihat pengaruh PKH pada layanan kesehatan preventif yang memang indikator-indikatornya dapat dibentuk dari kedua tahapan survei. Studi ini tidak mampu melakukan analisis dampak PKH terhadap, misalnya kualitas dan ketersediaan layanan kesehatan, cakupan antenatal dan postnatal, angka kesakitan, status gizi, status kesehatan, kemiskinan, dan lain-lain. Alasannya tidak semua informasi yang dikumpulan dalam survei dasar digali kembali dalam survei lanjutan PKH 2008. ${ }^{1}$ Padahal, survei dasar telah mengumpulkan informasi lengkap dan berguna untuk mendeteksi dampak PKH pada berbagai aspek kesehatan tersebut. ${ }^{5}$

Survei lanjutan juga tidak mengumpulkan data sosial demografi, ekonomi, dan karakteristik wilayah dengan rinci. Hal ini mengakibatkan keterbatasan variabel pada tingkat individu, rumah tangga serta lokasi. Keterbatasan lainnya adalah adanya perubahan status rumah tangga intervensi menjadi rumah tangga kontrol atau sebaliknya. Ini mengakibatkan homogenitas kelompok kontrol dan intervensi pada awal survei/intervensi menjadi terganggu 
(misal imunisasi BCG). Padahal sifat heterogenitas diantara kedua kelompok merupakan permasalahan dalam penggunaan metode DD. Alternatif perbaikan yakni kombinasi DD dengan propensity matching score (PSM), untuk menyamakan homogenitas diantara kedua kelompok intervensi dan kontrol dengan terpaksa juga tidak dapat dilakukan karena keterbatasan variabel sosial ekonomi, demografi, dan karakteristik lokasi yang dikumpulkan dalam survei lanjutan PKH 2008. ${ }^{17}$ Sedikitnya jumlah sampel pada survei lanjutan tidak mendukung penggunaan PSM karena semakin memperkecil ukuran sampel yang dapat dianalisis lebih lanjut. Aplikasi metode ekonometrik lain seperti two-stage least square (2 SLS) dan generalized method of moments (GMM) untuk mengoreksi kemungkinan endogenitas atau seleksi bias PKH karena randomisasi PKH hanya terjadi pada kecamatan juga tidak dapat dilakukan. Penggunaan 2 SLS dan GMM membutuhkan variabel instrumen, yang dapat dibentuk jika variabel sosial ekonomi dan demografi tersedia. ${ }^{18}$ Variabel instrumen ini harus berhubungan dengan PKH tetapi tidak dengan indikator evaluasi dan orthogonal dengan random error proses atau eksogen.

\section{Kesimpulan}

Penelitian ini bertujuan untuk mendeteksi dampak PKH terhadap penggunaan layanan kesehatan preventif. Rancangan yang digunakan adalah eksperimen dengan melibatkan kelompok intervensi PKH dan kontrol yang keduanya dipilih secara acak. Sumber data diperoleh dari data survei dasar dan data survei lanjutan PKH. Survei lanjutan dilakukan setelah setahun uji coba, namun hanya mencacah $10 \%$ responden yang dicacah dalam survei dasar. Hasil estimasi metode double-difference menunjukkan PKH secara rata-rata menaikkan kunjungan ke posyandu sebesar 3\%, pemantauan tumbuh kembang anak 5\%, dan kegiatan imunisasi sebesar $0,3 \%$. Studi ini menyimpulkan bahwa meskipun uji coba PKH baru memasuki ulang tahun pertama dan pelaksanaan program relatif belum optimal, PKH berhasil meningkatkan pemanfaatan layanan kesehatan preventif.

\section{Saran}

Penelitian ini merupakan evaluasi dampak PKH tahap awal karena pelaksanaan program di semua lokasi uji coba belum berusia setahun ketika data survei lanjutan dikumpulkan. Hasil-hasil harus ditafsirkan dengan hatihati mengingat adanya sejumlah keterbatasan studi. Temuan studi juga harus divalidasi dalam evaluasi dampak PKH lebih lanjut dengan mengoptimalkan ketersediaan data survei lanjutan tahun 2009. Data survei lanjutan 2009 dikumpulkan pada akhir tahun 2009 menggunakan kuesioner dan standar kualitas sama dengan survei dasar 2007. Jumlah sampel survei lanjutan
2009 juga cukup berimbang dengan sampel survei dasar 2007.

\section{Ucapan Terima Kasih}

Peneliti mengucapkan terima kasih kepada Bappenas dan Bank Dunia yang sudah memberi kesempatan untuk menggunakan data survei dasar CCT 2007 dan survei PKH 2008. Pendapat yang tertulis dalam penelitian ini adalah murni dari peneliti, tidak merepresentasikan Bappenas maupun Bank Dunia. Semua bentuk kesalahan menjadi tanggung jawab peneliti.

\section{Daftar Pustaka}

1. Fiszbein A, Schady N. Conditional cash transfers: reducing present and future poverty. Washington DC: World Bank Policy Research Report; 2009.

2. Pemerintah Republik Indonesia. Pedoman umum program keluarga harapan. Jakarta: Pemerintah Republik Indonesia; 2007.

3. Badan Perencanaan dan Pembangunan Nasional Republik Indonesia. Deteksi dini dampak program keluarga harapan. Jakarta: Direktorat Perlindungan dan Kesejahteraan Masyarakat, Deputi Bidang Kemiskinan, Ketenagakerjaan, dan UKM Badan Perencanaan dan Pembangunan Nasional Republik Indonesia; 2007.

4. Maluccio JA, Flores R. Impact evaluation of a conditional cash transfer program: the Nicaraguan red de protección social. Washington DC: IFPRI Research Report 141, International Food Policy Research Institute; 2005.

5. World Bank. Conditional cash transfers in Indonesia: program keluarga harapan and PNPM-generasi baseline survey report. Jakarta: World Bank; 2008.

6. Castanada T. Laporan stocktaking PKH 2008. Jakarta: World Bank; 2008.

7. Badan Perencanaan dan Pembangunan Nasional Republik Indonesia. Laporan survei lanjutan PKH 2008. Jakarta: Direktorat Perlindungan dan Kesejahteraan Masyarakat, Deputi Bidang Kemiskinan, Ketenagakerjaan dan UKM Badan Perencanaan dan Pembangunan Nasional Republik Indonesia; 2008.

8. Shahidur RK, Gayatri BK, Hussain AS. Handbook on impact evaluation: quantitative methods and practices. Washington DC: World Bank; 2010.

9. Pemerintah Republik Indonesia. Pedoman operasional PKH bagi pemberi pelayanan kesehatan. Jakarta: Pemerintah Republik Indonesia; 2007.

10. Gertler PJ. Do conditional cash transfers improve child health? evidence from PROGRESA's control randomized experiment. American Economic Review. 2004; 94 (2): 336-41.

11. Adato, Michelle, Terence R, Natalia S, Elif A, Nurfer C, Sema C. An evaluation of the conditional cash transfer program in Turkey: second qualitative and anthropological study. Washington DC: International Food Policy Research Institute; 2007.

12. Hidayat B. Penetapan persyaratan kesehatan program bantuan tunai bersyarat di Indonesia. Jakarta: Mimeo; 2006.

13. Adato M, Hoddinott. Conditional cash transfer programs: a 'magic bullet'? Washington DC: International Food Policy Research Institute.

14. Behrman JR, Hoddinott J. Programme evaluation with unobserved he- 
terogenity and selective implementation: the mexican progresa impact on child nutrition. Oxf Bull Econ Stat. 2005; 67 (4): 547-569.

15. Attanasio O, Go'mez LC, Heredia P, Vera HM. The short-term impact of a conditional cash subsidy on child health and nutrition in Colombia. 2005.

16. Barham, Tania, John M. The effect of conditional cash transfers on vaccination coverage in Nicaragua. Health and Society Working Paper
HS2008-01, Institute of Behavioral Science, University of Colorado at Boulder, CO; 2008.

17. Dehejia R. Practical propensity score matching: a reply to smith and todd. Journal of Econometrics. 2005; 125: 355-364.

18. Hidayat B, Pokhrel S. The selection of an appropriate count data model for modelling health insurance and health care demand: case of Indonesia. Int. J. Environ. Res. Public Health. 2010; 7: 9-27. 